\title{
Conflict Between Doing Well And Doing Good? Capital Budgeting Case Study - Coors
}

Julia S. Kwok, Northeastern State University, USA

Elizabeth C. Rabe, Northeastern State University, USA

\begin{abstract}
Considering the paradox of drinking what you drive and driving what you drink, Coors Brewing Company's conversion of spilt beer into ethanol is interesting and timely because of today's intensified need for alternate fuels. The decision of investment in a sustainable project was present in 1996 as well as today. It is evident that Coors considered sustainability before it became popular. Their ethanol project allows an examination of several business issues that pertain to finance, accounting, operations management and environmental management students. This case has provided students sufficient information to practice the whole capital budgeting process which includes identifying and forecasting cash flows, applying capital budgeting tools and performing sensitivity and scenario analysis. Finance students will focus on cash flows and the capital budgeting aspect of the case. The potential reduction of waste disposal cost and generation of revenues from ethanol production will also be of interest to cost accounting students who focus on cutting costs in the production process. From a management standpoint, the Coors Brewing Company and Merrick's ethanol project serves as an example of how a company can make a profit while engaging in environmentally safe projects. This illustrates the coexistence of company performance and ethicality.
\end{abstract}

Keywords: capital budgeting; cost accounting; ethics; alternative fuel; waste disposal; ethanol

\section{INTRODUCTION}

$\mathscr{I}$ n 1996, Coors Brewing Company of Golden, Colorado, was approached with an innovative proposal by local engineering firm Merrick and Company. The idea was to produce ethanol as a fuel additive. Triggered by rising fuel costs and a government mandate to reduce air pollution levels in the Denver area, a local market for ethanol had opened up and was expected to have future growth. Fuel blenders were required to add a fuel oxygenate, such as ethanol, to all gasoline sold in the Denver area. The Federal government also offered $\$ 0.51$ tax refund per gallon of ethanol as an incentive to fuel blenders. Companies, for instance, Total Petroleum, a Denver area refining company, had considered building an ethanol plant, but found the cost of transporting the raw materials prohibitive (Local Engineering Firm Unveils New Plant That Doubles Ethanol Production, 2005). However, a brewery which already had processes in place and waste materials available that could be further processed into ethanol, would be able to operate an ethanol plant without the added cost of transportation (Miller, 2008).

Creating a bio-mass alternative fuel from waste presented Coors with an opportunity to be innovative, environmentally friendly, and community-minded. It would be the first major U.S. brewery to produce an alternative fuel that fit the paradox of "Drink what you drive and drive what you drink." Coors was spilling between 18 and 22 million gallons of beer every year, equivalent to six cans of beer per second (Gavora, 1996). The evaporation of the spilled beer releases ethanol, a Volatile Organic Compound (VOC), into the air. The production of ethanol would allow Coors to reduce its annual levels of VOCs emissions by 70 tons (Molson Coors Donates Beer Waste Ethanol for Democratic National Convention Flex-Fuel Vehicles, 2008). Coors found the opportunity of 
reducing VOC attractive considering they had previously been fined \$1-million by the Colorado Department of Health for VOC emission violations (Gavora, 1996). Ethanol production would also provide a public image of being environmentally friendly or "green" as its product helped reduce local air pollution. Merrick's proposal involved changing waste disposal process, committing resources for operation and capital expenditure for a new distillation facility capable of producing 1.5 million gallons of ethanol annually (Sanchez, 2005).

\section{COMPANY HISTORY}

Coors Brewing Company was founded as a family business in 1873 by Adolph Coors. The company dedicated itself to brewing quality beverages that appeal to a broad base of customers. By 1996, Coors had expanded the variety and brands of beverages offered (Adolph Coors Company 1996 Annual Report, 1996). Even when faced with increased competition and costs, the company had consistently performed well and its stock prices continued to rise (TAP- Historical Prices for Molson Coors Co CL B -Yahoo! Finance, 2008).

\section{THE ETHANOL PROJECT}

Coors had formed a variety of alliances to capitalize on synergies. CEO Peter Coors needed to decide if working together on ethanol production with Merrick and Company would be a beneficial alliance.

Merrick's proposed ethanol project would be located in Golden, $\mathrm{CO}$ at the Coors brewery. At that time Coors had excess facilities and land available. Building the fracturing distillery in Golden meant that brewery waste could be easily transferred to the distillation area at little or no cost.

Former CEO Bill Coors considered waste to be "a resource out of place." (Molson Coors Donates Beer Waste Ethanol for Democratic National Convention Flex-Fuel Vehicles, 2008). Steven Wagner, Merrick's vice president believed that the ethanol project would take a waste stream and turn it into a revenue steam (Sanchez, 2005). Of course, college students would be thrilled with the idea of "Drinking (beer) for Gas."

With the ethanol project, Coors could repurpose up to $95 \%$ of its waste removed from spent yeast (Coors Pledges to Cut Emissions by 12\%, 2007) and used it as the raw material for ethanol production (Miller, 2008). Waste beer and obsolete beer would be diverted from sewage treatment to the ethanol process, thereby recovering ethanol that would had been a part of the plant's Volatile Organic Compounds (VOCs) emissions (Molson Coors Donates Beer Waste Ethanol for Democratic National Convention Flex-Fuel Vehicles, 2008). The dry spent yeast would continue to be sold to a pet feed producer.

The beer brewing process involved combining grains, malt, hops, and water to create a "mash". This mash was then brewed in brewing kettles. The liquid produced, wort, was drained off and yeast added to it for the fermentation process. After fermentation was complete, the finished product, beer, was transferred to tanks for bottling. The spent yeast was waste that could be used in ethanol production or be sold to pet feed producers (AP-42, CH9.12.1: Malt Beverages, 1996).

To produce ethanol, waste beer was combined to produce a liquid containing $12-17$ proof ethanol (From Grains to Gas, 2008) which ran through a "fractional distillation" process. A 200 proof ethanol was produced (R. Paine, personal communication, October 30, 2008) when heat is used to separate the ethanol from other liquids (Kvaalen, Wankat, \& McKenzie, 1984). This ethanol was then sold to local gasoline blenders to be added to the fuel to create gasahol. Gasahol was by volume $10 \%$ ethanol.

The fact that the market is local was an advantage of using the Golden location (Miller, 2008). This local market was a result of the environmental challenges faced by the Denver area. The air pollution in the metropolis triggered Federal regulations that created this local ethanol market (Miller, 2008). By producing ethanol, Coors could reduce both motor vehicle and industry emissions (Molson Coors Donates Beer Waste Ethanol for Democratic National Convention Flex-Fuel Vehicles, 2008). 
Coors' CEO, Peter Coors, saw that there were factors that could make an alliance with Merrick mutually beneficial. Coors had the property, raw materials, and manpower to operate the project (Miller, 2008). Merrick had experience in designing and constructing fractioning towers. Their alliance could create competitive advantages that would reduce the riskiness of the project.

\section{PROJECT EVALUATION}

Prior to the investment decision, Peter and the Financial Manager, John, needed to evaluate whether the project would break even and meet the environmental requirement of the disposal of waste beer. Coors would be satisfied with breaking even if the project would reduce further VOC emission, helping them to avoid future fines. The investment analysis started with a forecast of future cash flows. Capital budgeting evaluation tools such as net present value and equivalent annual annuity would be used to evaluate the value of the project. To evaluate the impact of changes of key variables such as sales and ethanol prices on the feasibility of the project, sensitivity and scenario analysis would be performed.

\section{Relevant Cash Flows}

Cost of production usually consists of direct material, overhead, and direct labor. John needed to obtain operational information on a variety of costs and potential revenues. He asked the Product Manager, Rick, to assist him identifying relevant cash flows for the ethanol project. Rick had been with the company for a long period of time. He knew the ins and outs of the beer production process. After some research, Rick shared his findings with John. "In the proposed project, spilled beer and spent yeast, are the only raw materials needed for the generation of ethanol. There is no additional cost for those items because spilled beer is a waste product, and spent yeast is a byproduct generated from the normal beer brewing process. To make the pure ethanol fuel graded ethanol, 5\% gasoline must be added. The current price per gallon of gasoline is \$1.09" (Historical US Retail Gasoline Prices, DOE).

"Don’t we currently sell the yeast to pet feed producers?" John asked.

"Yes," Rick replied, "We do, as wet yeast. Once the yeast goes through the distillation process, it would continue to be sold to the feed producers as dry yeast. We could actually see a savings in transportation costs. Without the ethanol project, the freight costs are $\$ 300$ per truck for 30 trucks per day. The cost of transporting the yeast after the liquid is extracted would be reduced significantly. I anticipate a savings of $\$ 0.30$ of transportation cost for each dollar of ethanol revenue received by Coors."

“That addressed the direct material costs, what about direct labor?” John asked.

"The project will use $10 \%$ of a factory worker's time to manage the yeast drying process. The average factory worker's wages are $\$ 9.33$ per hour (The Bureau of Labor Statistics). Coors will use a total of seven employees for each of the three eight-hour shift per day in the ethanol distillation process." Rick said.

“What about overhead?" John asked.

Rick replied, 'Coors' overhead for this project which includes utilities, maintenance cost of the machines and the buildings, administrative expenses related to the project, and product safety management cost, would be shared with Merrick."

John added, "By the way, Merrick will be responsible for all the start up cost which includes cost of the infrastructure, machinery and equipment, shipping and testing of equipment, initial training, pipe, insulation installations and rewiring of the building. I estimate cost to Coors would be $30 \% / 2=15 \%$ of the revenue (Farm Business Management, 2007 and Income statement of Great Plains Renewable Energy). In researching ethanol prices I have found that the average wholesale price, also known as the rack price, of ethanol over the past 5 years 1991-1995) was around \$1.20 per gallon (Nebraska Ethanol Board). It is selling at $\$ 1.35$ per gallon currently, but I 
expect the price to return to around $\$ 1.20$ per gallon. It should remain relatively stable for the next 5 years (Ethanol and Unleaded Gasoline Average Rack Prices). That would be approximately 20 cents per gallon of ethanol.”

"I think we already are recovering ethanol for our own energy needs. If we stop burning ethanol in our boilers, it may increase our utilities costs?" John pondered.

"True, we do recover some low-grade ethanol from our waste-stream and use it to fuel the boilers to generate steam," Rick replied. "It saves about $2 \%$ of the plant fuel costs. Unfortunately, it also reduces the useful life of the boiler, so we are forced to replace the equipment sooner than its expected life, offsetting the benefits of utilizing the ethanol in house." project cost.

"What about the capital investment for this project?" Rick was curious to know how much the ethanol

John considered this for a moment. "Actually, capital expenditure for Coors will be insignificant. According to the proposal for partnership with Merrick, Merrick would construct the infrastructure for the project as well as the distillation towers. Coors would provide land that it already owns for the plant. Currently there is no alternative use for the land. Coors won't even need to borrow money for the project. That covers the cost portion of the project," John pointed out.

"Now we need to cover revenues, what can we expect in production?" John inquired.

Rick responded, “The proposed plant's initial production capacity is 1.5 million gallons per year. The projected production for the first year is 1.3 million gallons and is expected to grow at rate of $15 \%$ from 1996 to 1997 and a growth rate of 34\% from 1997 to 1998. Production should reach 2 million gallons in 1998.

"Due to this being a joint venture, Coors would realize a portion of the revenues" John injected. "The revenue from sale of ethanol would be split between Coors and Merrick in a 30/70 split. Coors would expect to get $30 \%$ of the revenue per gallon of ethanol, i.e. 40 cents per gallon when the rack price is $\$ 1.20$ per gallon."

"I have heard there are tax incentives amounting to 61 cents per gallon for ethanol producers. Will that benefit Coors?" Rick asked.

"Unfortunately no," John replied, "the 61 cent per gallon is actually two different tax incentives. There is a 10 cent per gallon small-producer tax credit for biomass ethanol (CRS Issue Brief for Congress, 2005. Table 1: Current Energy Tax Incentives and Taxes: Estimated Revenue Effects). Due to the way the alliance would be structured, Merrick, not Coors, would qualify for the tax credit. The second tax incentive is a refund of 51 cents per gallon for fuel blenders using ethanol. It does not directly affect Coors, however it will keep the net price of ethanol competitive."

"This proposal is beginning to sound like a good investment for Coors," Rick exclaimed. "Don't jump to conclusion that fast. I'll need to evaluate the feasibility of the project," John said it calmly. "Let's talk about it after I do my assessment."

\section{Weighted Average Cost of Capital (WACC)}

"Should I use the company's weighted average cost of capital (WACC) or a comparable's beta to calculate this project's cost of capital?" John puzzled. He would like to discuss the issue with the CEO, Peter Coors. In the next couple days, John gathered data for the calculation of the weighted average cost of capital (WACC). First he collected data for the calculation of the required rate of return of equity. He calculated the average risk free rate for 3 month Treasury Bills was around 4.31\% (Bureau of Labor Statistics and Federal Reserve). Through his research, he estimated that the average market returns based on 1991-1995 monthly data was 12.6\% (Yahoo Finance). The market risk premium based on 1991-1995 S\&P 500 Index data was $8.29 \%$ (12.6\% minus $4.31 \%$ ). The average inflation rate from 1991-1995 based on consumer price index is 3.1\%. He planned to use this to get the real discount 
rate to discount the project's cash flows (the U.S. Department of Labor Bureau of Labor Statistic). Coors tax rate for 1996,1995 , and 1994 were $42 \%, 41.1 \%$, and $44.2 \%$ respectively.

Next, he reviewed data about the capital structure of the company. The 1995 Coors annual report contains information on the market values and interest rates of various types of long-term debt (see exhibit 1). He also found the number of common stocks outstanding was around 38 million shares. On December 31, 1995, and December 25, 1994, 25 million shares of $\$ 1$ par value preferred stock were authorized but un-issued (Coors 1996). Common stock price of Coors in the first half of 1996 was around \$8 (TAP).

After some basic research, he went to his boss, Peter, for advice on what WACC should be used. "Peter, we have to think about which WACC we should use for our ethanol project. Should I use the company's WACC or should I use a different WACC for the ethanol project. For the prior choice, I know the beta of our company is 0.65. Since we would be a pioneer in the ethanol production, it is hard to find groups of companies that can be used as our comparables. So, for the latter, I have chosen Great Plains Renewable Energy (GPRE), an ethanol producer, as our most compatible competitor. Great Plains' beta is estimated to be 1.84. These calculations are based on the regression results of the past five years' monthly returns of Coors, GPRE and S\&P 500 Index (historical prices in yahoo finance), "John provided. John furthered, "If we choose an incorrect WACC, we may end up accepting a project that should not be accepted. "John, you have raised a very good question. Unfortunately, I am not sure about the answer. Let me think about it. Meanwhile, how about calculating WACCs based on the company as well as GPRE's beta and then run a sensitivity analysis of the impact of changes of WACC on NPV? "Peter puzzled.

\section{Qualitative Analysis}

"I am concerned also about the guideline of accepting a project that just breaks even if the project is environmentally friendly. How will our investors view this? Would that negatively affect Coors' stock price?” John asked.

Peter Coors thought for a moment and said, "I believe that stewardship of the environment was both a personal responsibility and a public value (Peter Coors on Environment). We must evaluate the quantitative as well as the qualitative aspects of the project. We should take into account of the economic, environmental and social issues related to the project. Economically, I feel pretty good about the diversification benefits of investing in ethanol production because ethanol production is an unrelated business to Coors' beer production. John, examples of qualitative issues that you should be considered are: reducing VOC emission that pollute the air at an estimated savings of $\$ 33.00$ per tC of Carbon Dioxide; providing ethanol additives that minimize the carbon footprint of the environment; and providing positive public relations for the company by being a good steward of the environment.

\section{CONCLUSION}

After the meeting with Peter, John knew he had a lot of work to do. Based on the information Rick provided to him, he had to forecast the project's cash flows to produce a Performa Income Statement. Then he had to decide what would be the appropriate beta for the calculation of the WACC. Once he got the discount rate figure out, he had to use that to evaluate the feasibility of the ethanol project. He also needed to run the sensitivity analysis that Peter had asked him to perform. In addition, John felt that he should investigate how sensitive his analysis would be to changes of key variables and different economic and operational conditions. So he had to think about how his result change with changes of input variables, such as demand of ethanol, states of the economy, oil crisis, increased competition from alternative fuels, as well as operational efficiency.

Even though there was a ton of work to be done, John was thrilled to have the opportunity to be part of a pioneer team that initiated this environmentally sound, sustainable "green" project... and he couldn't help but smile when he thought that someday he will be pulling up to a pub to fill up instead of a gas station.

\section{QUESTIONS}

1. How do mangers know whether this project is a value-enhancing project to the company? What is the appropriate capital budgeting tool to analyze the benefits of the project? 
2. What are the relevant, incremental cash flows for this project? What is the initial outlay? What are the costs and benefits over time?

3. What is the appropriate opportunity cost of capital (hurdle rate) for the project? Should Peter Coors use the company's weight average cost of capital and why?

4. Should the project be implemented based on quantitative analysis?

5. Would changes of the assumptions about the demand for the ethanol, hourly wages, rack price of ethanol and operational efficiency affect the value of the project? How sensitive are the results to the assumptions made?

6. In addition to the financial analysis, what qualitative factors should be considered prior to making the final decision on the approval of the project?

7. What conclusion can managers make about the perceived tradeoff of doing well and doing good?

\section{AUTHOR INFORMATION}

Dr. Julia Kwok is an Associate Professor of Finance at Northeastern State University-Broken Arrow. Dr Kwok teaches graduate and undergraduate investment and corporate finance. Her research interests include sustainability, neural network, corporate governance, venture capital and spectrum licensing issues. She has recently published and presented at conferences on sustainability, institutional structure, telecommunications, academic assessment and pedagogy. Dr Kwok serves as officials of the Southwestern Finance Association as well as the Southwestern Case Research Association. She is also a member of the Financial Management Association, Southern Finance Association, Phi Beta Delta International Scholars, Phi Kappa Phi, Golden Key Honor Society and Beta Gamma Sigma.

Ms. Elizabeth Rabe is an Instructor of Accounting at Northeastern State University. She is an active Certified Public Accountant. Ms. Rabe teaches accounting courses in managerial accounting, accounting information systems, business policy and intermediate accounting areas. Her research interests include writing teaching cases, life-cycle accounting, business sustainability and student assessment. She participated in American Accounting Association and presented at Southwestern Case Research Association and 2010 National Conference on Learner Centered Teaching. She is a member of the Institute of Management Accountants, Oklahoma Society of Certified Public Accountants, Petroleum Accountant Society of Oklahoma and Southwestern Case Research Association.

\section{REFERENCES}

1. Adolph Coors Company 1995 Annual Report (1995). Molson Coors Annual Report Archives. MolsonCoors.com. Retrieved September 122008 from http://idea.sec.gov/Archives/edgar/data/24545/0000024545-96-000003.txt

2. Adolph Coors Company 1996 Annual Report (1996). Molson Coors Annual Report Archives. MolsonCoors.com. Retrieved September 122008 from http://library.corporateir.net/library/10/101/101929/items/265118/COORS_AR1996.pdf

3. AP-42,CH9.12.1: Malt Beverages (1996). U.S. Environmental Protection Agency. Retrieved September 12, 2008 from http://www.epa.gov/ttn/chief/ap42/ch09/final/c9s12-1.pdf

4. Consumer Price Index Data from 1913 to 2010, US Inflation Calculator. Retrieved October 13, 2010 from http://www.usinflationcalculator.com/inflation/consumer-price-index-and-annual-percent-changes-from1913-to-2008/

5. Coors Pledges to Cut Emissions by 12\% (2007). Denver Business Journal. Retrieved September 15, 2008 from http://www.bizjournals.com/denver/stories/2007/12/03/daily34.html?q=Molson\%20Coors\%20Donates\%20 Beer\%20Waste\%20Ethanol\%20for\%20Democratic\%20National\%20Convention\%20FlexFuel\%20Vehicles\%20denver\%20post

6. CRS Issue Brief for Congress. (2005). Energy Tax Policy (Order Code IB10054). Retrieved January 12, 2009 from http://www.ncseonline.org/NLE/CRSreports/05apr/IB10054.pdf

7. Damodaran, Aswath, 1999, Estimating equity risk premiums, unpublished working paper, New York University, New York, NY. Retrieved January 31, 2009 from: http://pages.stern.nyu.edu/ adamodar/pdfiles/papers/riskprem.pdf. 
8. Federal Reserve Statistical Release. Retrieved from October 5, 2010 from http://www.federalreserve.gov/releases/H15/data/Annual/H15 TB M3.txt

9. $\quad$ From Grains to Gas (2008). MolsonCoors.com. Retrieved September 15, 2008 from http://molsoncoors.com/responsibility/environmental-responsibility/from-grains-to-gas/302/

10. Gavora, J. (1996). EPA greenmails the states. The Policy Review, Nov/Dec 1996. Retrieved Oct 11, 2010 from http://findarticles.com/p/articles/mi_qa3647/is_199611/ai_n8740925/

11. Historical US Retail Gasoline Prices, DOE. Retrieved October 5, 2010 from http://www.eia.gov/oil_gas/petroleum/data_publications/wrgp/mogas_history.html

12. Kvaalen, E., Wankat, P., McKenzie, B. (1984). Alcohol Distillation: Basic Principles, Equipment, Performance Relationships, and Safety. Purdue Extension, Purdue University. Retrieved September 12, 2008 from http://www.ces.purdue.edu/extmedia/ae/ae-117.html

13. Local Engineering Firm Unveils New Plant That Doubles Ethanol Production (2005). Merrick.com. Retrieved September 12, 2008 from http://www.merrick.com/news/press/2005/Nov\%2018\%20Ribbon\%20Cutting\%20at\%20Coors.pdf

14. Miller, David. Beer Brewer Converts Waste into Resource (2008). Market-to-Market, Iowa Public Television. Retrieved September 11, 2008 from http://www.iptv.org/mtom/archivedfeature.cfm?Fid=464

15. Molson Coors Brewing Company 2006 Annual Report (2006). Molson Coors Annual Report Archives. Retrieved September 12, 2008 from http://media.corporateir.net/media files/irol/10/101929/reports/2006AnnualReportEN.pdf

16. Molson Coors Brewing Company History (2008). Mergent Online. Retrieved September 12, 2008 from http://www.mergentonline.com.jvlapps.nsuok.edu/compdetail.asp?company=2141\&Page=history

17. Molson Coors Donates Beer Waste Ethanol for Democratic National Convention Flex-Fuel Vehicles (2008). MolsonCoors.com. Retrieved Sept 12, 2008 from http://www.molsoncoors.com/newsroom/pressreleases/19-2008/484-molson-coors-donates-beer-waste-ethanol-for-democratic-national-convention-flexfuel-vehicles

18. Nebraska Ethanol Board, Lincoln, NE. Nebraska Energy Office, Lincoln, NE. Retrieved January 12, 2009 from http://www.neo.ne.gov/statshtml/66.html

19. Peter Coors on Environment (2004). On the Issues. Retrieved November 24, 2009 from http://www.issues2000.org/Domestic/Pete Coors Environment.htm.

20. Sanchez, Robert. Coors Ramping Up Production of Ethanol from Beer Waste (2005). The Denver Post. Retrieved September 11, 2008 from http://www.detnews.com/2005/autosinsider/0510/25/01-358749.htm

21. Schnitkey, G., Good D., Ellinger, P, Farm Business Management: Farm Economics Facts and Opinions, Department of Agricultural and Consumer Economics, 2007. Retrieved on January 13, 2009 from mpra.ub.uni-muenchen.de/5151/1/MPRA_paper_5151.pdf

22. TAP- Historical Prices for Molson Coors Co CL B -Yahoo! Finance (2008). Yahoo.com. Retrieved September 13, 2008 from

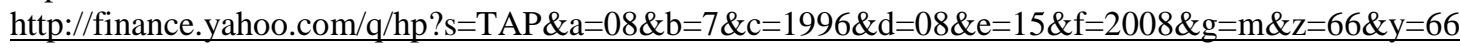




\section{EXHIBIT 1}

The 1995 Portion of Debt Information from Note 4 of Coors' Balance Sheet

Long-term debt consists of the following: $\quad$ As of December 31, 1995

$\begin{aligned} \text { Interest } & \text { Market } \\ \text { Rate } & \text { Value* }\end{aligned}$

(In Thousands)

Medium-Term Notes

$8.9 \%$

$6.9 \%$

$\$ 134,000$

Senior Notes

$4.1 \%$

106,000

Industrial Development Bonds

$------$

4,000

TOTAL

244,000

* Market values were determined using discounted cash flows at current interest rates.

Source: Extracted from note 4 of Coors' 1995 10-K. 